DOI https://doi.org/10.30525/978-9934-26-173-2-15

\title{
ПРИНЦИПИ ПРОФЕСІЙНОГО НАВЧАННЯ «СОЦІАЛЬНИХ ВІЗИТЕРІВ» У ЛАТИНСЬКІЙ АМЕРИЦІ В 1920-Х РОКАХ
}

\author{
Зайченко Н. I. \\ доктор педагогічних наук, \\ доцент кафедри сочіальної роботи та освітніх і педагогічних наук \\ Національний університет "Чернігівський колегіум» \\ м. Чернігів, Україна
}

У 1920-х роках у латиноамериканському регіоні започатковується професійне навчання соціальних працівників. Заснування перших шкіл благочинної соціальної допомоги в країнах Латинської Америки (Чилі, Аргентина, Уругвай) було пов'язано зі своєрідним явищем «соціального візитерства». Гостро стояла проблема нестачі професійних кадрів соціальних помічників у галузі охорони здоров'я. Боротьба 3 інфекційними захворюваннями й епідеміями відбирала сили лікарів i медсестер, а хворі люди потребували постійного повсякденного догляду.

Ідеї про систематичне професійне навчання «соціальних візитерів» соціальних помічників у галузі охорони здоров'я у країнах південного конусу (Чилі, Аргентина, Уругвай, Парагвай) на початку 1920-х років стали настільки актуальними й злободенними, що втілювалися в життя 3 незвичайною швидкістю. Чилійський лікар Алехандро дель Ріо (Alejandro del Rio Soto Aguilar) в квітні 1924 року звернувся до Ради благочинності м. Сантьяго із пропозицією зорганізувати школу для підготовки соціальних візитерів за прикладом бельгійських шкіл, із досвідом яких він ознайомлювався безпосередньо під час подорожі до Західної Свропи. Отримавши позитивну відповідь, А. дель Ріо запросив до Сантьяго Рене Санда (Rene Sand) - колегу, представника адміністративної ради Центральної Школи соціальної роботи у Брюсселі, щоби він допоміг влаштувати заклад професійної підготовки соціальних візитерів. I 4 травня 1925 року в м. Сантьяго розпочала діяльність перша в латиноамериканському регіоні школа благочинної соціальної допомоги (пізніше названа на честь Алехандро дель Ріо). Керівником школи було призначено бельгійську викладачку Жені Берньер (Jeny Bernier). Мета школи визначалася таким чином: «підготовка діячів - учасників у сфері охорони здоров'я» [1, с. 37-38].

У країнах південного конусу практика соціальної допомоги в першій половині XX ст. була тісно пов'язана з галуззю медицини й поширенням «гігієнічного» та «візитерського» напрямів суспільно-благочинної 
діяльності. Саме «гігієністи» були ініціаторами запровадження курсів $\mathrm{i}$ шкіл соціальної допомоги (первинна назва шкіл соціальної роботи) в Аргентині. Лікар Альберто Званк (Alberto Zwank) у 1924 році започаткував курс «візитерів - соціальних гігієністів» на медичному факультеті Університету Буенос-Айресу, які би могли здійснювати соціально-профілактичну роботу 3 місцевим населенням задля перешкоджання поширенню різних хвороб (туберкульозу, холери, жовтої лихоманки) [2, с. 75].

Освітні заклади для підготовки «соціальних візитерів» засновувало й Відділення Червоного Хреста в Аргентині. 3 ініціативи Ніколаса Лосано (Nicolas Lozano) й Хорхе Ховарда (Jorge Howard) в 1928 році було відкрито школу самаритян в Буенос-Айресі, в якій здійснювали навчання окремо «соціальних гігієністів» та «шкільних гігієністів» [2, c. 78].

Протягом 1929 року школи самаритян було засновано також в аргентинських містах Сан-Хуані, Сантьяго-дель-Естеро, Мендосі [2, c. 80].

Тоді ж розпочала діяльність друга чилійська школа соціальної допомоги, названа на честь благодійниці Ельвіри Матте де Кручаги (Elvira Matte de Cruchaga). Ця школа підпорядковувалася Чилійському католицькому університету [3, с. 106].

Явище «візитерства» було поширеним у країнах Латинської Америки i в XIX ст. Здебільшого «візитерами» виступали медичні сестри, благодійники, охочі допомагати тяжко хворим й приреченим людям. Однак професійних навичок психологічної та соціальної роботи 3 хворими особами «візитери», звісно, не мали. Організація перших шкіл благочинної соціальної допомоги в латиноамериканському регіоні певним чином сприяла розв'язанню цієї проблеми. Школа Алехандро дель Ріо скоро здобула собі славу в Латинській Америці, до неї приїздили на навчання з віддалених куточків регіону.

42 учениці чилійської школи благочинної соціальної допомоги наприкінці 1926 року вперше в історії країни отримали дипломи підтвердження кваліфікації «соціального візитера» [4, с. 17].

Професійне навчання в школах соціальної допомоги, започатковане в латиноамериканському регіоні в середині 1920-х років, мало відповідати певним педагогічним вимогам та принципам, зокрема, принципам науковості; поєднання теоретичного і практичного навчання; міцності знань; раціонального синтезу індивідуальних й колективних форм роботи та деяким іншим. Навчання в перших чилійських школах соціальної допомоги продовжувалося два роки. У школі Алехандро дель Ріо теоретичне навчання здійснювалося від 1 квітня до 31 серпня, 
а в жовтні - грудні - учениці направлялися до різних благочинних установ на практичне навчання під керуванням вчителів своєї школи $[4$, c. 25$]$.

Протягом першого року навчання в зимовому семестрі викладалися предмети «Громадянське виховання», «Психологія і соціальна економія», «Гігієна та деонтологія», «Догляд за хворими», «Загальні основи харчування і дієтики», «Діловодство. Статистика», «Мораль». У літньому семестрі - відбувалося практичне навчання в установах державного і приватного благодійництва, в сеттльменті, в інституціях громадського обслуговування, в лікарнях. Протягом другого року навчання в зимовому семестрі передбачалося освоєння таких предметів, як: «Законодавство про гігієну та благочинність», «Соціальна економія», «Виховання дітей», «Догляд за пораненими», «Спеціальне харчування і дієтика», «Бухгалтерія», «Організація державного благодійництва», «Соціальне обслуговування за різними напрямами», а в літньому семестрі - знову учениці відправлялися до благочинних установ на практичне навчання. Завершувалося загальне навчання в школі підсумковим іспитом, який проводився в другій половині грудня і до якого допускалися тільки за умови, що всі попередні випробування було подолано [4, с. 26-27].

Керівниця чилійської школи благочинної соціальної допомоги Жені Берньєр вказувала: «<..> справа соціальної допомоги - довідуватися, боротися, настановляти. Боротися - 3 упередженнями, зі злощасними звичками чи пороками; протистояти - хворобам та неуцтву. Настановляти - означає вчити мистецтву життя - більш здоровішому, щасливішому й плодотворному» [4, с. 34].

На погляд Жені Берньєр, головне, чому майбутні соціальні візитери мали навчитися в школі, - це вмінням підтримувати, спрямовувати й порадити. «Необхідний дух пожертвування, забуття про себе, [необхідний] дух спільності. Формується цей дух в любові до народу, в глибокій повазі до людської істоти, у вірі в їі удосконалення», підкреслювала педагогиня [4, с. 34].

На переконання Алехандро дель Ріо, школи соціальної допомоги обов'язково мають давати змогу учням обирати й вузьку спеціалізацію соціального візитерства відповідно до тих галузей суспільної діяльності, в яких має місце соціальне обслуговування, включаючи і індустрію, i бібліотечну справу, і т. п. [5, с. 409].

Фундаторками іншої чилійської школи соціальної допомоги були сестри Ребека і Адріана Іскієрдо Філліпс (Rebeca, Adriana Izquierdo Phillips), а керівницею було призначено німецьку викладачку Луїзу 
Йоринссен (Louise Joerinssen), яка раніше очолювала школу католицького соціального служіння в Мюнхені [6, с. 58].

Як стверджувала педагогиня Моніка Хіменес (Monica Jimenez de Barros), школа соціальної допомоги, названа на честь Ельвіри Матте де Кручаги, «трималася на трьох підпорах: по-перше, на християнській доктрині; по-друге, на науковому й практичному знанні, привнесеному з Європи, в основному з Німеччини та Бельгії; по-третє, на багатстві доброчинностей двох славетних чилійських родів Матте-Кручаги i Іскієрдо Філліпс» [6, с. 58].

Провідною метою школи було підготовлення соціальних помічників на засадах духовно-моральних цінностей християнського милосердя. Становлення цієї школи соціальної допомоги здійснювалося під егідою Чилійського католицького університету [6, с. 58].

Таким чином, із середини 1920 -х років у латиноамериканському регіоні було започатковано професійне навчання «соціальних візитерів». В авангарді - були чилійські школи благочинної соціальної допомоги школа Алехандро дель Ріо та школа Ельвіри Матте де Кручаги. Ці перші в Латинській Америці заклади професійного навчання «соціальних візитерів» різнилися і за змістовими компонентами навчання, i за формами його організації, однак переслідували єдині цілі - сформувати контингент справжніх професійних соціальних помічників, які би служили громаді й соціуму.

\section{Лiтература:}

1. Neira M. Antologia del trabajo social chileno. Concepcion: Universidad de Concepcion, 1998. 223 p.

2. Oliva A. Trabajo social y lucha de clases: analisis historico de las modalidades de intervencion en Argentina. Buenos Aires: Imago Mundi, 2007. 197 p.

3. Trabajo social en algunos paises: aportes para su comprencia. Mexico: UNAM, 2004. 275 p.

4. La Escuela de Servicio Social de Santiago de Chile. Servicio Social. 1927. № 1-2, ano 1. P. 8-41.

5. Rio A. Consideraciones sobre el personal auxiliar del medico, de la sanidad y del servicio social. Revista de Beneficencia Publica. Santiago, septiembre de 1925. T. IX, № 3. P. 396-411.

6. Homenaje a Rebeca Izquierdo, fundadora Escuela de Trabajo Social. Revista de Trabajo Social. 1977. № 23 (septiembre - noviembre). P. 57-64. 